\title{
CENTRAL NATIONAL SECURITY COMMISSION OF THE COMMUNIST PARTY OF CHINA
}

The article discusses the rationale for, and progress made to actual date, of creating the Central National Security Commission of the Communist Party of China, from when it was first announced in November 2013. The paper highlights the development and reasons for creating the Commission. The main impulses for establishment of the Commission are to help better coordinate a fragmented Communist Party of China bureaucracy and to speed up president Xi Jinping's drive for consolidation of his personal power over the internal and external coercive and diplomatic tools of the governing structure. The creation of the Commission is a work in progress and its full institutional maturation will take a certain period. It is still an open question as to whether this institutional attempt to achieve coordination of the foreign and security policy areas around of president's authority will improve, or further complicate, China's long-standing coordination problem, and help to solve some current internal and external security policy challenges. Beyond the president Xi Jinping's steps it is difficult to discern an authoritative voice. His political progress in the consolidation of foreign and security policy, however, is remarkable and very dynamic. The Commission's focus looks to be mainly oriented to internal and periphery security, but it is also the People's Republic of China response to new global and transnational issues.

Keywords: Central National Security Commission, Communist Party of China, People's Republic of China's Foreign and Security Policy

\section{INTRODUCTION}

States, in favor of their decision-making on fundamental issues of national security, set up competent structures. This solution within the complex process of current development was recently adopted also by People's Republic of China.

Since the Communist Party of China (CPC) came to power in 1949, at the time of the Cold War, international relations were shaped by the ideology and thus relatively clearly defined the People's Republic of China (PRC) national security policy. The highest political leaders with personal wartime experiences did not feel the need to establish an overarching body dealing with issues of national security. Questions of national security were a matter for decision of the "Supreme Leader", respectively of a small group of his fellow parties. This approach was maintained until the end of the Cold War.

The global development, the increased complexity of security problems ${ }^{2}$ and the growing importance of the PRC as an important driving force and power, brought the need to review the management structure of national security.

\footnotetext{
${ }^{1}$ Jozef Žigray, Faculty of Political Science and International Relations, Matej Bel University in Banská Bystrica, Kuzmányho 1, 97401 Banská Bystrica, Slovak Republic, e-mail: jozef.zigray@umb.sk

${ }^{2} \mathrm{R}$. Ivančík, P. Nečas, International security from the view of postmodern conflicts on the African continent, Amelia, Rzeszów 2012, s. 168.
} 
Third (Jiang Zemin) and fourth (Hu Jintao) generations of leaders were gradually losing their absolute personal control over security policy which, in addition, gradually became the suitable subject of political balance between the CPC factions.

Decision-making on national security was fragmented between National People's Congress (Parliament), President, State Council (Government) and Central Military Commission (Military). Political control of the CPC was guaranteed through party structures like Central Committee of the CPC, Political Bureau of the CPC Central Committee (Politburo) and particularly Standing Committee of the Central Political Bureau of the $\mathrm{CPC}$ - in that time, the only authority able to solve immediately all urgent strategic issues of national security.

China's political leaders rightly realized the lack of authority like the U.S. National Security Council (U.S. NSC). The first attempt to create a competent authority in the CPC structures was the establishment of the CPC Central Committee National Security Leading Small Group (NSLSG) in $2000^{3}$.

NSLSG main task was to coordinate national security policy with the CPC Central Committee Foreign Affairs Leading Small Group. Other commission (such as the CPC Central Political and Legal Affairs Commission) had competencies particularly in the area of internal security and political stability of the state.

The growth of global and regional importance of the PRC over the last decade has brought new security challenges and difficulties to manage them by domestic actors as well as in cooperation with an increasing number of foreign players.

Traditional threats to national security have been extended to nontraditional threats and internal risks with a negative impact on political, economic and social situation of the state. While the complexity and interconnection of domestic and foreign security threats tended to grow, these have not been solved because of the decentralization of competent structures, the absence of integrated strategy and unified policy management.

With aim to stop these trends, the Chinese political leaders decided to create the Central National Security Commission as a highest decision-making body solving all issues of the state security.

\section{CENTRAL NATIONAL SECURITY COMMISSION OF THE COMMUNIST PARTY OF CHINA}

On November 12, 2013, the Third Plenary Session of the 18th Chinese Communist Party's Central Committee approved a number of significant decisions and reforms regarding security issues. One of the most important decisions was announcement about establishment of a new Central National Security Commission of the Communist Party of China (CNSC).

President Xi Jinping, in his explanation on the establishment of CNSC pointed out that China faces the dual pressure of safeguarding national sovereignty, security, and development interests externally and safeguarding political security and social stability inter-

\footnotetext{
${ }^{3}$ Allegedly, the establishment of the NSLSG in 2000 was in response to China's failure to produce a timely, well-coordinated reaction after the NATO bombing of the Chinese Embassy in Belgrade. There have also been abundant arguments that the establishment of the NSLSG in 2000 originated from President Jiang Zemin's desire to build a platform to continue to exercise his influence after his retirement in 2002. His initial effort to establish a Chinese National Security Council was opposed by certain senior civilian and military leaders, which resulted in the establishment of the NSLSG as a compromise.
} 
nally; all kinds of predictable and unpredictable risk factors have significantly increased 4

According to Joel Wuthnow from CNA China Studies, the purpose of establishing as well as expected benefits of the CNSC are:

- Resolving security policy coordination problems, including reducing stove-piping in China's bureaucratic system.

- Steering policy at a high level. This includes discussion about whether foreign NSCs might be a useful model in the Chinese context.

- Addressing a wide array of domestic and international security challenges, ranging from terrorism to the U.S. rebalance to Asia ${ }^{5}$.

Zhao Kejin from Carnegie-Tsinghua Center for Global Policy explained the main reasons for establishment of the CNSC:

- The first goal in establishing the CNSC is to help ensure the success of the deepening economic, political, and social reforms that are being carried out in China.

- The second goal of the CNSC is to establish a unified national security system.

- The third goal is to support the leadership and policy objectives of the $\mathrm{CPC}^{6}$. According to U.S. - China Economic and Security Review Commission, four responsibilities of the CNSC with respect to each of these issues are:

- stipulating and implementing national security strategy;

- pushing forward the construction of the rule of law system concerning national security;

- setting security principles and policies of national security work;

- conducting research and studying ways to resolve major problems in national security work ${ }^{7}$.

According to Zhao Kejin, the CNSC has three primary tasks:

- to advise the Politburo, which oversees the CPC, and the highest levels of leadership in matters of strategy and security;

- to carry out strategic coordination between the different departments, and to unify the departments throughout the party, the government, the military, and society;

- to conduct crisis management and risk management, for both internal and external security threats ${ }^{8}$.

The expected composition of the CNSC (not yet officially confirmed) is as follows:

\section{Chairman:}

${ }^{4}$ J. Xi, Explanation Related to The Decision of the CCP Central Committee on Several Problems of Fully Deepening Reform, Xinhua, 15 November 2013, http://news.xinhuanet.com/politics/2013-11/15/c_118164294.htm.

5 J. Wuthnow, Decoding China's New National Security Commission, CNA China Studies, https://www.cna.org/CNA_files/PDF/CPP-2013-U-006465-Final.pdf.

${ }^{6}$ K. Zhao, China's National Security Commission, Carnegie-Tsinghua Center for Global Policy, 2015, http://carnegietsinghua.org/2015/07/09/china-s-national-security-commission/id7i.

${ }^{7}$ U.S.-China Economic and Security Review Commission, Hearing on Stability in China, Lessons from Tiananmen and Implications for the United States, written testimony of Murray Scot Tanner, 15 May 2014 http://origin.www.uscc.gov/sites/default/files/transcripts/Hearing\%20Transcript_May\%2015\%202014.pdf. Xinhua (English edition), Xi Explains China's Reform Plan, November 15, 2013, http://news.xinhuanet.com/english/china/2013-11/15/c $\square 132891949 . h t m$

${ }^{8}$ K. Zhao, China's National Security Commission, Carnegie-Tsinghua Center for Global Policy, 2015, http://carnegietsinghua.org/2015/07/09/china-s-national-security-commission/id7i. 
- Xi Jinping, General Secretary of the CPC, President of the PRC, Chairman of the Central Military Commission (CMC);

- Vice Chairmen:

- Li Keqiang, Premier of the State Council, Politburo Standing Committee member;

- Zhang Dejiang, Chairman of the National People's Congress Standing Committee, Politburo Standing Committee member;

Members:

- Meng Jianzhu, executive member, Politburo member, Secretary of the Central Political and Legal Affairs Commission;

- Zhang Chunxian, member, Politburo member, Party Secretary of Xinjiang;

- Li Zhanshu, Chief of General Office of the CNSC, Chief of the General Office of the CPC;

- Cai Qi, deputy chief of General Office of the CNSC.

The CNSC has the status as an agency directly under the Central Committee of the CPC. The country's highest leaders are members of the CNSC. This makes the CNSC the most comprehensive an powerful national security decision-making body in the Chinese security system ${ }^{9}$.

The CNSC held its first meeting in April 2014.

In a speech at the meeting, president Xi stressed the connection between national security and economic development: Development is the foundation for security, and security is a condition for development. Only a prosperous country can have a strong military, and only a strong military can protect the country. The combination of domestic stability and external security might have been what president Xi meant when he called for China to follow a national security path with Chinese characteristics ${ }^{10}$.

The CNSC formation is an important step in centralization of power into the hands of the highest party leadership with two primary implications:

- the top party leadership has now direct control over internal and external national security decision-making;

- president Xi can now better regulate civilian and military sides of the foreign and security apparatus to control national security agenda.

As it has been confirmed by Chinese Television The paramount leader himself is designated to lead on foreign/military affairs, which gives him an unparalleled position in determining the country's national security policies ${ }^{11}$.

The first meeting of the CNSC suggested that the issues of internal and external security will be evaluated in balance. Stressing the Commission's powers, president Xi used several times expressions unified and efficient to describe the role of the new CNSC.

\footnotetext{
${ }^{9}$ As NDU's Senior Colonel Xu Hui explains, if the country's highest leader were a member of the commission, it would serve as China's highest decision-making organ for national security. However, if it were led by other senior leaders, it might only serve as a decision-making advisory organ. China News Service, Experts Demystify China's National Security Committee, Standard Configuration of Strong Powers, "China News Service", 14 November 2013, http://www.chinanews.com/gn/2013/11-14/5499845.shtml.

10 S. Tiezzi, China's National Security Commission Holds First Meeting, "The diplomat" 2014 http://thediplomat.com/2014/04/chinas-national-security-commission-holds-first-meeting/.

${ }^{11}$ China Central Television, Focus Today, 13 November 2013, http://news.cntv.cn/2013/11/13/VIDE1384353 122424699.shtml.
} 
The area of responsibilities of the CNSC is very wide as it covers: political security, homeland security, military security, economic security, cultural security, societal security, scientific and technologic security, information security, ecological security, natural resources security, nuclear security. The list of responsibilities of the CNSC allows to negotiate virtually all national security issues. Current approaches of the top PRC political leadership point to the fact that issues are very complex and interdependent.

The CNSC's mandate covers both internal and external security issues; however, official Chinese statements, Chinese academics, policy experts, and Chinese state media indicate it likely will focus on the former ${ }^{12}$.

According to Fudan University Associate Dean, Shen Dingli, the CNSC's internal focus suggests president $\mathrm{Xi}$ has determined domestic factors pose the most substantial challenge to China's national security for decades to come ${ }^{13}$.

Wen-Ti Sung assesses that if president Xi truly is able to make the CNSC the primary national security decision-making body as he promised, then we may expect to see a more coherent Chinese foreign policy, and witness fewer incidents where the foreign policy team's charm offensive towards its neighbors are rendered moot by ill-timed military exercises or provocations in the South China Sea and beyond. China watchers, especially, may be entitled to feel generally less concerned about future provocative offhand remarks by Chinese military officers, wondering whether they represent the official security poli$\mathrm{cy}^{14}$.

Despite the importance of CNSC, in deciding on matters of national security, not forgetting role of the original and still functioning structures remains significant. Varying degrees of impact on the security policy of PRC have particularly those authorities:

- XI Jinping (General Secretary of the CPC, President of the PRC, Chairman of the CMC, Chairman of the CNSC (paramount leader deciding daily routine national security affairs);

- Standing Committee of the Central Political Bureau of the CPC (deciding particularly serious and urgent issues on an ad hoc or weekly meetings);

- Political Bureau of the CPC Central Committee (deciding important issues and key policies);

- Central Committee of the CPC (Significant but not urgent issues, such as changes in existing guidelines and principles);

- CPC Central Committee National Security Leading Small Group (ad hoc issues in coordination particularly with CPC Central Committee Foreign Affairs Leading Small Group);

- Central Political and Legal Affairs Commission of the CPC (deciding ad hoc issues with coordination with other CPC Central Committee Leading Small Groups on internal security);

\footnotetext{
${ }^{12}$ A. Erickson, W. McCahill, Take Heed of China's Security Commission, "China Real Time Report (Wall Street Journal blog)", 31 January 2014, http://blogs.wsj.com/chinarealtime/2014/01/31/pay-close-attentionto-chinas-new-security-commission/; available at: http://csis.org/files/publication/Pac13810.pdf.

13 D. Shen, Framing China's National Security, "China-US Focus", 23 April 2014, http://www.chinausfocus.com/peace security/framing-chinas-national-security/.

${ }^{14}$ S. Wen-Ti Sung, China's New State Security Committee, The diplomat", 25 November, 2013, http://thediplomat.com/2013/11/chinas-new-state-security-committee/.
} 
- Central Military Commission of the CPC (deciding important issues on security and foreign affairs regarding to the military).

Another more popular, but simplified, categorization divides national security affairs into routine issues and strategic issues, which fall respectively under the authority of the paramount leader and the Political Bureau of the CPC Central Committee. The roles of the Political Bureau and Central Committee in policy decisions are negligible; because in reality they rarely challenge a consensus already reached by the Political Bureau of the CPC Central Committee ${ }^{15}$.

China's CNSC can be comparable to the U.S. NSC as both institutions deliberate and coordinate national security policies. Differences between them are that the CNSC is a CPC structure while the U.S. NSC is a governmental structure. Further, China's CNSC appears to have a much broader mandate, mainly on domestic issues, than the U.S. NSC. The CNSC is also an interministerial administrative body for coordination and planning of the PRC's security policy. However, some of the Chinese experts draw attention to more potential differences between CNSC and Western countries' similar structures.

According to Gong Fangbin, a professor at China's NDU, there would be large differences between CNSC and Western countries' national security councils or their equivalents, since we are a country under the leadership of a Communist Party, and Party Central will continue to have the highest decision-making power ${ }^{16}$.

Similarly, a Xinhua analysis asserted that such comparisons to other NSCs were for reference purposes only ${ }^{17}$.

In addition, Senior Colonel Xu Hui, another NDU scholar, stated more circumspectly that different countries have differing systems, and the roles and statutes of all NSCs are different ${ }^{18}$.

PRC experts agree that China should have the ability to set and execute security policy from a high level, but often they offer differing perspectives on which model is the most suitable for how to do so.

Questionable is the current position of the original party decision-making structures on security and foreign policies. At present, the CPC has the Leading Small Group on Foreign Affairs and the Leading Small Group on National Security. The both civilian groups have responsibilities in the area of foreign and security policies. Internal security is mainly under control of the CPC Central Political and Legal Affairs Commission. To the CPC is also available the Central Military Commission, chaired by president Xi, that coordinates security and foreign policies with China's military. These bodies are likely to be fully subordinated to the CNSC. Mechanism of communication in the development and management of national security policy is not yet clear.

\footnotetext{
${ }^{15}$ China News Service, Experts Demystify China's National Security Committee, Standard Configuration of Strong Powers, 14 November 2013, http://www.chinanews.com/gn/2013/11-14/5499845.shtml.

${ }^{16}$ F. Gong, National Security Committee Carries the Duty of Resolving the Trouble of Rising Powers, "People's Daily Online, Great Power Forum", 14 November 2013, http://www.people.com.cn/n/2013/1114/c34740723539919.html.

${ }^{17}$ China News Service, Experts Demystify China's National Security Committee, Standard Configuration of Strong Powers, 14 November 2013, http://www.chinanews.com/gn/2013/11-14/5499845.shtml.

${ }^{18}$ China News Service, Experts Demystify China's National Security Committee, Standard Configuration of Strong Powers, 14 November 2013, http://www.chinanews.com/gn/2013/11-14/5499845.shtml.
} 


\section{CONCLUSION}

The CNSC will play a crucial role as a guiding force in national security decisions and policies of the PRC. Foreign and Security Policy of the PRC are very closely linked and at the same time fragmented into civilian and military parts. Their direction and control have so far been divided between the State Council (Government) and the CMC (Military). Coordination was carried out on an ad hoc form of Leading Small Groups' meetings. The creation of the CNSC allowed to CPC to centralize foreign and security policies as well as their subordinate structures.

President XI as chairman of the CMC has already control over military issues. Thanks to the presidency of the CNSC he received further control and influence over the internal security and foreign policy. This will strengthen the office of the PRC's presidency at the expense of the CPC's general secretary position, currently carried out by one person.

President Xi has strengthened control over national security policy and consolidated his power only a year after taking office. He remarkably put an end to decades of fruitless efforts of his predecessors.

Despite important structural changes it is not likely to see significant changes in China's national security policy. Rather, it is to be expected the better coordination and closer centralization and consolidation of power in the hands of the CPC Politburo Standing Committee members.

The importance of the new CNSC deserves permanent attention of PRC's and foreign security experts and scholars.

\section{REFERENCES LIST}

[1] China Central Television, Focus Today, 13 November 2013, http://news.cntv.cn/2013/11/13/VIDE1384353122424699.html.

[2] China News Service, Experts Demystify China's National Security Committee, Standard Configuration of Strong Powers, 14 November 2013, http://www.chinanews.com/gn/2013/1114/5499845.shtml.

[3] Erickson A., McCahill W., Take Heed of China's Security Commission, "China Real Time Report (Wall Street Journal blog)”, 31 January 2014, http://blogs.wsj.com/chinarealtime/ 2014/01/31/pay-close-attention-to- chinas-new-security-commission/; available at: http://csis.org/files/publication/Pac13810.pdf.

[4] Gong F., National Security Committee Carries the Duty of Resolving the Trouble of Rising Powers, "People's Daily Online, Great Power Forum", 14 November 2013, http://www.people.com.cn/n/2013/1114/c347407-23539919.html.

[5] Ivančík R., Nečas P., International security from the view of postmodern conflicts on the African continent, Amelia, Rzeszów 2012.

[6] Shen D., Framing China's National Security, "China-US Focus", 23 April 2014 http://www.chinausfocus.com/peace security/framing-chinas -national-security/.

[7] Tiezzi S., China's National Security Commission Holds First Meeting, "The diplomat" 2014, http://thediplomat.com/2014/04/chinas-national-security-commission-holds-first-meeting/.

[8] U.S.-China Economic and Security Review Commission, Hearing on Stability in China. Lessons from Tiananmen and Implications for the United States, written testimony of Murray Scot Tanner, 15 May 2014, http://origin.www.uscc.gov/sites/default/files/transcripts/ Hearing\%20Transcript_May\%2015\%202014.pdf.

[9] Wuthnow J., Decoding China's New National Security Commission, "CNA China Studies", https://www.cna.org/CNA_files/PDF/CPP-2013-U-006465Final.pdf. 
[10] Wen-Ti Sung S., China's New State Security Committee, The diplomat”, 25 November 2013, http://thediplomat.com/2013/11/chinas-new-state-securi-committee/.

[11] Xi J., Explanation Related to The Decision of the CCP Central Committee on Several Problems of Fully Deepening Reform, "Xinhua", 15 November 2013, http://news.xinhuanet.com/ politics/2013-11/15/c_118164294.htm.

[12] Xinhua (English edition), Xi Explains China's Reform Plan, November 15, 2013, http://news.xinhuanet.com/english/china/2013-11/15/c $\square$ 132891949.htm.

[13] Zhao K., China's National Security Commission, Carnegie-Tsinghua Center for Global Policy 2015, http://carnegietsinghua.org/2015/07/09/china-s-national-securitycommission/id7i.

\section{CENTRALNA KOMISJA BEZPIECZEŃSTWA NARODOWEGO}

W artykule omówiono przyczyny utworzenia Centralnej Komisji Bezpieczeństwa Narodowego Komunistycznej Partii Chin, która została powołana w listopadzie 2013 r. W artykule przedstawiono powstanie Komisji, podano jej główne cele, jak również ukazano jej rozwój, jaki dokonał się od momentu jej powstania. Głównym impulsem powołania Komisji była lepsza i sprawniejsza koordynacja władzy Komunistycznej Partii Chin oraz przyspieszenie działań prezydenta Xi Jinping w umocnieniu swojej władzy nad przymusem wewnętrznym i zewnętrznym oraz narzędzi dyplomatycznych struktury zarządzającej. Zadaniem Komisji Bezpieczeństwa Narodowego jest reagowanie na kryzysy w kraju i za granicą. Komisja nadal się kształtuje i aby osiągnąć jej instytucjonalną dojrzałość, potrzeba jeszcze czasu. Wciąż kwestią otwartą jest to, czy próba osiągnięcia koordynacji i bezpieczeństwa dotycząca obszarów polityki zagranicznej jest możliwa i czy utworzenie takiego organu, jak Komisja Bezpieczeństwa Narodowego, poprawi bądź jeszcze bardziej skomplikuje długotrwałe problemy koordynacyjne Chin, bądź też pomoże rozwiązać niektóre wewnętrzne, jak również zewnętrzne wyzwania polityki bezpieczeństwa. Patrząc na działania prezydenta Xi Jinpinga, nietrudno dostrzec jego autorytatywny głos. Jednak jego działania na rzecz postępu politycznego dotyczącego konsolidacji polityki zagranicznej i bezpieczeństwa są niezwykłe i bardzo dynamiczne. Komisja kładzie nacisk przede wszystkim na bezpieczeństwo wewnętrzne państwa, ale jest to również pewnego rodzaju odpowiedź Chińskiej Republiki Ludowej na nowe problemy globalne i międzynarodowe.

Słowa kluczowe: Centralna Komisja Bezpieczeństwa Narodowego, Komunistyczna Partia Chin, Polityka Zagraniczna i Bezpieczeństwa Chińskiej Republiki Ludowej

\section{DOI: 10.7862/rz.2016.mmr.11}

Tekst złożono w redakcji: luty 2016

Przyjęto do druku: maj 2016 